\title{
ARTYKULY
}

\author{
Radosław Zyzik
}

\section{POJĘCIE OSOBY - JEDNO CZY WIELE?}

Few words have as many layers of meaning as person. The complexity of the word's history, almost impossible to unravel, corresponds to this multiplicity of meanings, and almost from the beginning this history reflects the word's various aspects of meaning that cannot be synthesized ${ }^{1}$.

Hans Urs Balthasar

\section{ZAGADNIENIA WSTĘPNE}

$\mathrm{Na}$ temat pojęcia osoby napisano wiele. Jest ono jednym $\mathrm{z}$ niewielu terminów, które są żywo dyskutowane zarówno na gruncie filozofii, teologii, prawa, jak i - od niedawna - również w obrębie nauk przyrodniczych. Problemy związane $\mathrm{z}$ naturą pojęcia osoby są więc złożone i wymagają uważnej analizy przeprowadzonej z perspektywy interdyscyplinarnej. Filozoficzne dyskusje dotyczące natury pojęcia osoby często mają widoczny wpływ na spory z pogranicza nauk społecznych i prawnych. W trakcie takich dyskusji analizowane są bardziej szczegółowe kwestie (zagadnienie statusu "osoby” a dopuszczalność aborcji, eutanazji czy zapłodnienia in vitro) ${ }^{2}$. Ponadto oprócz filozofii, etyki (bioetyki) i prawa, „osoba” zajmuje szczególne miejsce w siatce pojęciowej teologii. Co więcej, w związku

\footnotetext{
${ }^{1}$ H.U. Balthasar, On the concept of person, „Comunnio” 1986, nr 13 (1), s. 19-24.

${ }^{2}$ Zob. J. English, Abortion and the Concept of a Person, „Canadian Journal of Philosophy” 1975, nr 5, s. 233-243.
} 
z dynamicznym rozwojem nauk neurobiologicznych zaczęły pojawiać się dyskusje nad rolą tego terminu w rozważaniach poświęconych filozoficznym interpretacjom danych neuronaukowych, odnoszących się do takich zagadnień, jak świadomość podmiotu, jego tożsamość czy ciągłość w czasie.

W niniejszym tekście poruszone zostaną dwa zagadnienia. Po pierwsze, podjęta zostanie próba zilustrowania różnych znaczeń pojęcia osoby w zależności od dziedziny, w której jest ono używane. Przedyskutowana zostanie jego rola w filozofii, teologii i naukach przyrodniczych. Po drugie, przedstawione zostanie uzasadnienie tezy, że obecnie nie posługujemy się tylko jedną definicją osoby (ten cel jest możliwy do osiągnięcia dzięki realizacji pierwszego punktu). Funkcje, jakie pełni to pojęcie w różnych siatkach terminologicznych, uniemożliwiają wypracowanie wspólnej definicji.

Wniosek płynący z tych rozważań będzie miał charakter metodologiczny. Mianowicie obecnie (ważne i potrzebne) spory dotyczące problemów bioetycznych - takich jak: zapłodnienie in vitro czy dopuszczalność eutanazji - wykraczają poza wąską dziedzinę filozofii i należy z największą ostrożnością dyskutować zagadnienia, w ramach których przeplatają się argumenty z zakresu teologii, etyki, nauk neurokognitywnych i prawa.

\section{HISTORIA POJĘCIA OSOBY}

Historia pojęcia osoby jest niezwykle złożona i bardzo interesująca. W tej części pracy przedstawione zostaną różne koncepcje osoby, które wyrosły na gruncie teorii sztuki, nauk prawnych, teologii i filozofii. Każda z tych wizji pojawiła się w określonym czasie i kontekście. Pełnią one odmienne role i funkcje, są elementami różnych siatek pojęciowych, a tym samym - każda zasługuje na odzielną analizę.

2.1. Osoba i Jej znaczenie teatrologiczne. Pojęcie osoby nie funkcjonowało w językach kultur starożytnych w znaczeniu, jakie się mu przypisuje dzisiaj. Nie jest to jednak zaskakujące, jeśli zauważymy, że starożytny obraz świata znacznie różnił się od tego współczesnego ${ }^{3}$. Wydaje się, że w celu poszukiwania pierwszych znaczeń pojęcia osoby należy przyjrzeć się bliżej nie filozofii czy językowi potocznemu, ale teorii sztuki.

${ }^{3}$ Zob. np. L. Kołakowski, Moje słuszne poglądy na wszystko, Znak, Kraków 2011. 
Pojęcie osoby pierwotnie pochodzi od etruskiego terminu phersu ${ }^{4}$, oznaczającego maskę, którą zakładał aktor na scenie teatralnej. Była to więc nazwa rekwizytu teatralnego, symbolizującego określoną cechę postaci. $\mathrm{Z}$ kolei w starożytnej grece występował termin prosopon, również utożsamiany z maską używaną $\mathrm{w}$ przedstawieniach teatralnych. Początkowo łacińskie pojęcie persona miało takie same znaczenie jak phersu i prosopon. Dlatego - co do zasady - w literaturze przyjmuje się, że pierwszym znaczeniem pojęcia osoby było tak zwane znaczenie teatrologiczne ${ }^{5}$. Należało do słownika teorii sztuki, a wykorzystywane było zwłaszcza w przypadku przedstawień przed dużą publicznością.

Konsekwencje znaczenia teatrologicznego są interesujące. Aktor mógł być „nośnikiem” co najmniej kilku osób, a każda z nich reprezentowała konkretną cechę osobowości. Przyjmuje się, że nurt teatrologiczny nawiązywał do jeszcze bardziej pierwotnego znaczenia tego słowa - wcześniej odnosiło się po prostu do twarzy, oblicza. Termin prosopon, rozumiany jako „maska”, zaczął powoli przenikać do filozofii. Jednak utożsamiany był on ciągle nie z człowiekiem, a z rolą, jaką ów miał do odegrania w świecie, społeczeństwie i państwie. Nie zachodzi więc w tym miejscu znacząca zmiana znaczeniowa w stosunku do rozumienia teatrologicznego. „Osoba” funkcjonowała pierwotnie jako pojęcie z języka sztuk teatralnych, które z rzadka tylko służyło do filozoficznego opisu sposobu, w jaki człowiek funkcjonuje w większych społecznościach ${ }^{6}$.

Fakt ten stanowi punkt wyjścia dla wszystkich, którzy utrzymują, że w filozofii greckiej brakuje wyraźnego pojęcia osoby; zarówno w pracach presokratyków, jak i w tekstach Platona i Arystotelesa, a nawet w przypadku dzieł filozofów znacznie późniejszych, piszących po łacinie, nie jest ono zdaniem części filozofów - używane. Sytuację tę opisuje Jan Maria Bocheński w rozmowie z Janem Parysem:

${ }^{4}$ Zob. H.U. Balthasar, On the Concept..., dz. cyt., s. 19.

${ }^{5}$ Zob. W.E. Ball, St. Paul and the Roman Law and Other Studies on the Origin of the Form of Doctrine, T\&T Clark, Edynburg 1901, s. 78.

${ }^{6}$ Zob. Epiktet, Encheiridion, [w:] http://filozofiauw.wdfiles.com/local--files/tekstyzrodlowe/Epiktet\%20-\%20Encheiridion.pdf (dostęp: 2 II 2012). 
Odpowiednika „osoby” u Arystotelesa, w jego filozofii, nie ma. Nie występuje. Co mu nie przeszkodziło być jednym z największych moralistów w dziejach. U św. Tomasza z Akwinu wyrażenie „persona” występuje bardzo często w teologii dogmatycznej. Ale w moralnej występuje tylko raz. Mianowicie w artykule De acceptione personarum. Przy mianowaniu na urzędy itp. uwzględnia człowiek swój stosunek osobisty do kandydata, a nie jego wartość. To jedyny przypadek, gdzie św. Tomasz używa wyrażenia osoba w swojej etyce, co mu nie przeszkodziło być wielkim moralistą ${ }^{7}$.

Wypowiedź Bocheńskiego wskazuje na kilka faktów, które należy odnotować. Zwolennicy twierdzenia, jakoby termin „osoba” nie funkcjonował w filozofii starożytnej, utrzymują - zgodnie z tym, co mówi Bocheński że chociażby Arystoteles nie używa w swoich analizach terminu prosopon ani persona. Stagiryta w swoim traktacie 0 duszy próbuje udzielić wyczerpującej odpowiedzi na pytanie, kim jest człowiek. W swojej analizie często posługuje się pojęciami duszy, substancji, ciała, zmysłów, rozumu, nigdzie jednak nie pisze o „osobie”. Bocheński zauważa, że w ramach swej antropologii filozoficznej Stagiryta nie zajmuje się w żaden sposób „osobą”. Wszelkie zaś próby „tworzenia” Arystotelesowskiej wizji osoby są przykładem myślenia ahistorycznego.

W ramach dygresji można zwrócić uwagę na pewien interesujący fakt, na który wskazuje Bocheński. Jeżeli przyjąć jego twierdzenie, to Arystoteles i św. Tomasz z Akwinu nie potrzebują pojęcia osoby, by zostać jednymi z najbardziej wpływowych etyków w historii filozofii. Bocheński zdaje się powiadać, że nie potrzebujemy tej idei, by mówić o godności jednostki ludzkiej.

Podsumowując, znaczenie początkowo przypisywane pojęciu osoby miało swoje korzenie w teorii sztuki i teatru. Dlatego w literaturze przedmiotu przyjmuje się, że pierwsze znacznie miało charakter teatrologiczny i pozostawało bez związku z filozofią, a także teologią. W takim wypadku w kolejnym kroku należy wyjaśnić, w jaki sposób pojęcie osoby wykroczyło poza obszar sztuki. W epoce starożytnej istniały co najmniej dwa inne kompletne schematy pojęciowe o charakterze (częściowo) autonomicznym:

${ }^{7}$ J. Parys, Między logika a wiara, Noir Sur Blanc, Warszawa 1998, s. 142. 
prawo rzymskie i teologia dogmatyczna. Koncepcja osoby wchodziła w skład obydwu.

2.2. RZYMSKIE KORZENIE PRAWA osób. Prawo rzymskie było systemem prawa, który obowiązywał i rozwijał się przez ponad tysiąc lat ${ }^{8}$. $\mathrm{W}$ ramach zagadnień podjętych $\mathrm{w}$ tej pracy kluczowe znaczenie ma okres klasyczny w rozwoju rzymskiego prawa prywatnego. W tym czasie pojęcie osoby zaczyna odgrywać ważną rolę w prawie Imperium Rzymskiego. Gajusz, wybitny jurysta rzymski, w swoich Instytucjach ${ }^{9}$ podzielił prawo na trzy działy: prawo osób, prawo ludzi i prawo powództw. Ze zrozumiałych względów najbardziej interesującym działem prawa jest prawo osób. W największym i najważniejszym dziele Gajusza - Instytucjach - możemy odnaleźć wiele interesujących nas definicji, takich jak:

Prawo osób, innymi słowy, prawo statusu, klasyfikuje ludzi na niewolników i wolnych, obywateli i obcych, rządzących i podwładnych ${ }^{10}$.

W książce z początku dwudziestego wieku - Św. Paweł i Prawo Rzymskie możemy przeczytać znacznie bardziej precyzyjną definicję:

W prawie rzymskim persona znaczyła jednostkę rozumianą na sposób pewnego statusu, zdolności, kondycji, które odróżnialne były od innych statusów, zdolności czy kondycji ${ }^{11}$.

Przywołane w tym zdaniu słowa wyrażają explicite to, co założone zostało w poprzednim cytacie. Być może Gajusz uznał, że nie musi skrupulatnie definiować pojęcia osoby, ponieważ jego znaczenie było powszechnie znane. Jest ono w prawie rzymskim czymś zgoła odmiennym od pojęcia człowieka, jest swoiście rozumianym statusem w sensie prawnym, czyli wiązką (zbiorem) uprawnień i obowiązków, które charakteryzują danego człowieka. Dobrze powyższą sytuację opisuje rzymska sentencja: Unus homo

${ }^{8}$ Początek prawa rzymskiego symbolicznie wiąże się z powstaniem Dwunastu Tablic (449 r. p.n.e.), a koniec jego obowiązywania przypada na zdobycie Konstantynopola w 1453 r. Oczywiście wpływ tego systemu reguł trwa nieprzerwanie do dziś.

9 Zob. Instytucje Justyniana, przeł. Cezary Kunderewicz, PIW, Warszawa 1986.

${ }^{10}$ Tamże, s. 79.

${ }^{11}$ W.E. Ball, St. Paul..., dz. cyt., s. 80. 
sustintet pluers personas - jeden człowiek może być jednocześnie kilkoma osobami, czyli może funkcjonować jako obywatel Imperium, paterfamilias, nauczyciel etc.

Co więcej, nie tylko człowiek mógł być osobą. Jeżeli termin persona był rozumiany na wzór statusu prawnego, to nic przecież nie stało na przeszkodzie, by za osoby uznać niektóre korporacje czy spółki, a odmówić tego przywileju niewolnikom. William Edmund Ball w swojej pracy trafnie zauważa, że:

Przez prawo osób rozumiane było prawo powiązane z różnego rodzaju zdolnościami lub statusem, dzięki którym ludzie znajdowali się w sytuacjach rozpoznawanych przez system prawa. Słowo „persona” nie było utożsamiane z pojęciem człowieka [...]. Można nawet założyć, że żaden autor piszący po łacinie nie używał pojęcia persona jako pojęcia konstytuującego jednostkę $e^{12}$.

Choć pojęcie osoby nie występowało w filozofii starożytnej, to w prawie rzymskim okresu klasycznego odgrywało istotną rolę. Prawo osób było jedną z trzech gałęzi systemu prawa Imperium Romanum. Prawnicze rozumienie "osoby” nie powstało ex nihilo. Widać wyraźnie, że nurt teatrologiczny, zgodnie z którym osoba była swoistą maską, stanowił podstawę prawniczej koncepcji osoby.

System prawa rzymskiego to nie jedyny obszar, w którym można było się spotkać z terminem persona. Teologia dogmatyczna wieków średnich oferuje nam zupełnie odmienne - choć równie interesujące - spotkanie z tą tematyką.

2.3. ROLA POJĘCIA OSOBY W SIATCE POJĘCIOWEJ TEOLOGII. Oprócz prawa rzymskiego łaciński termin persona zaczął przenikać do chrześcijańskiej teologii dogmatycznej. Pierwszym z teologów piszących po łacinie, który w sposób systematyczny zaczął wykorzystywać termin persona, był Tertulian. Jako człowiek świetnie wykształcony, Tertulian znał podstawowe kategorie prawa rzymskiego, zapoznany był również z filozofią grecką, a przede wszystkim - był jednym z ojców filozofii chrześcijańskiej. Te trzy elemnety złożyły się na oryginalność jego prac, w których próbował rozwiązać problemy teologii chrześcijańskiej (do czasów Tertuliana była

${ }^{12}$ Tamże, s. 79. 
greckojęzyczna) w zupełnie nowym systemie pojęciowym. Łacina oferowała nowe rozwiązania starych problemów, a prawo rzymskie stanowiło źródło inspiracji.

I tak po raz pierwszy łacińskie pojęcie osoby pojawiło się w tekście Przeciw Prakseaszowi Tertuliana, w którym autor próbował wyjaśnić tajemnicę Trójcy Świętej, stanowiącej jedno, będąc zarazem potrójną ${ }^{13}$. Tertulian pisał, że Bóg składa się z jednej substancji (łac. substantia), ale przejawia się w trzech osobach (łac. persona). Oznacza to, że Bóg ma jedną istotę, ale może przybierać trzy różne maski, mieć trzy twarze, z których każda eksplikuje inną cechę Boskiej natury.

Mimo nowej i ciekawej propozycji rozwiązania zagadnienia jedności Trójcy Świętej poprzez wprowadzenie pojęcia osoby, musiało upłynąć ponad sto lat zanim doceniona została jego użyteczność. W czwartym wieku odbyła się dyskusja dotycząca greckiego pojęcia hypostasis ${ }^{14}$. Wcześniej, na początku trzeciego wieku. pojawiły się problemy z tłumaczeniem greckich terminów na język łaciński. Bariery językowe pomiędzy światem greckim a rzymskim były na tyle poważne, że pojawiały się problemy językowe w teologii, które prowadziły niekiedy do herezji. Dlatego spory wokół pojęcia hypostasis zaowocowały bardzo ciekawym rozwiązaniem. Na pytanie, w jaki sposób Trójca jest czymś jednym, udzielono następujących wyjaśnień. Trójca jest jednością w ousia, czyli w swojej istocie (łacińskim odpowiednikiem terminu ousia było substantia). Z kolei na pytanie, w jaki sposób jedno jest Trójcą, padła następująca odpowiedź: Bóg ma - co prawda - jedną ousia (istotę), ale przejawia się $\mathrm{w}$ trzech hypostasis ${ }^{15}$, aktualizuje się ona w trojaki sposób, ma trzy twarze, z których każda eksplikuje inną cechę boskiej natury. Problem polegał na tym, że greckie hypostasis, podobnie jak ousia, było tłumaczone za pomocą tego samego łacińskiego słowa substantia. Takie przetłumaczenie ousia i hypostasis (za pomocą jednego terminu)

${ }^{13}$ Zob. Tertulian, Przeciw Prakseaszowi, [w:] Tertulian, Hipolit, Trójca Święta, WAM, Kraków 1997.

${ }^{14}$ Zob. J.L. Gonzáles, The Story of Christianity, Volume 1: The Early Church to the Dawn of the Reformation, Harper \& Row, Nowy Jork 2010, s. 91-93.

${ }^{15}$ Ojcowie Kapadoccy byli gorącymi zwolennikami powiązania pojęcia hypostasis z pojęciem prosopon. Por. A. Kijewska, Boecjusz i patrystyczne źródła koncepcji osoby, [w:] Personalizm polski, red. M. Rusecki, Wydawnictwo KUL, Lublin 2008, s. 21-52. 
prowadziło do uznania, że nie ma jednego Boga w swej istocie, a jest trzech bogów samoistnych.

By uniknąć niepotrzebnych problemów, tłumaczenie greckiego terminu hypostasis zmieniono na łacińskie subsistentia. Jednak to subtelne rozróżnienie zostało zapomniane, co znów doprowadziło do sporów pojęciowych i w konsekwencji do szerzenia się herezji. Dlatego zdecydowano się wrócić do schematu pojęciowego wprowadzonego przez Tertuliana w pracy Przeciw Prakseaszowi. Odbyło się to na Soborze Powszechnym w Aleksandrii, który miał miejsce w 362 roku. Hypostasis utożsamione zostało z łacińskim pojęciem persona, a greckie pojęcie ousia z pojęciem łacińskim substantia. Tak mniej więcej wyglądała siatka terminologiczna w myśli chrześcijańskiej czwartego wieku naszej ery.

Grzegorz z Nazjanzu ujął problem terminologii trynitarnej jako problem lingwistyczny, wskazując równocześnie na niedostatki języka łacinników:

\begin{abstract}
A więc u nas [Greków] mówi się prawowiernie o jednej istocie, a trzech hipostazach. Pierwsze słowo wyraża jedną naturę Boga, drugie, potrójne właściwości. Tak samo myślano w Italii. Ale z powodu ubóstwa swego języka i braku słów, mieszkańcy Italii nie mogli odróżnić hipostazy [substancji] i wprowadzili pojęcie trzech osób, aby nie przyjmować trzech istot. I co się stało? - Coś, co byłoby bardzo śmieszne, gdyby nie było raczej godne pożałowania, mianowicie różnicą wiary wydawała się drobna różnica w brzmieniu wyrazów! ${ }^{16}$
\end{abstract}

Spory z zakresu teologii trynitarnej nie ustały po Soborze Wyznawców $\mathrm{w} \mathrm{Nicei}^{17}$. Na ich kolejne odsłony nie trzeba było długo czekać. Następny sobór zwany chalcedońskim ${ }^{18}$ został zwołany w 451 roku. Podczas obrad potwierdzono wtedy dogmat Trójcy w formie zaproponowanej przez Sobór Nicejski:

Soborowe kanony przyjmują, że Osoby Trójcy Świętej stanowią trzy odrębne hypostasis. Mają one jednak tę samą naturę i dlatego uczestniczą

${ }^{16}$ Św. Grzegorz z Nazjanzu, Mowy wybrane, PAX, Warszawa 1967, s. 242.

${ }^{17}$ Zob. Breviarium fidei, red. J.M. Szymusiak, S. Głowa, Księgarnia Św. Wojciecha, Poznań 1964, s. 193-195.

${ }^{18}$ Zob. J.N.D. Kelly, Początki doktryny chrześcijańskiej, PAX, Warszawa 1988. 
w tej samej substancji - ousia. W ten sposób, mając wspólną naturę, Trójca Święta nie stanowi trzech bogów ${ }^{19}$.

Sobór nie rozwiązał palących problemów teologii dogmatycznej przez powtórzenie jedynie ustaleń sprzed stu laty. Co więcej, łacińskie pojęcie osoby zaczęło sprawiać kłopoty także w trakcie dyskusji chrystologicznych, gdzie dyskutowano kwestię, czy Chrystus jest dwóch natur i dwóch osób, czy jest w dwóch naturach i jednej osobie. Sytuacja stawała się zatem coraz bardziej skomplikowana.

Dyskusja o „osobie” w teologii chrześcijańskiej miała więc specyficzny charakter. Jej rozstrzygnięcia w sposób pośredni wpływały na obraz średniowiecznej Europy, dlatego uświadamiano sobie ich doniosłość i ciągle szukano adekwatnych zastosowań pojęcia osoby w teologicznej siatce pojęciowej. By uporać się ze wszystkimi powyższymi problemami, należało postarać się o jasne zdefiniowanie następujących pojęć: persona, substantia, subsistentia, hypostasis. Nie tylko definicje, ale także określenie wzajemnych zależności pomiędzy tymi terminami stanowiło o poprawności i adekwatności rozwiązania średniowiecznej wersji zagadki „osoby”.

Zadania tego podjął się Boecjusz, rzymski filozof i polityk, który zaproponował chyba najsłynniejszą $\mathrm{w}$ dziejach definicję osoby, zwaną zresztą definicją klasyczną: Persona est rationalis naturae individua substantia ${ }^{20}$. Jednakże zanim Boecjusz doszedł do sformułowania swojej definicji, wprowadził szereg rozróżnień terminologicznych, które stanowiły o sile i spójności jego definicji. Łacińskie pojęcie substystencji utożsamił z greckim pojęciem ousia; termin subsistentia $\mathrm{w}$ pracach Boecjusza oznacza byt, który istnieje samodzielnie (nie jest przypadłością). Z kolei pojęcie substantia - tak ważne dla Boecjańskiej definicji osoby - utożsamił z greckim pojęciem hypostasis, które oznacza byt, do którego przypadłości mogą należeć. Osoba to taka substantia, która jest racjonalna oraz indywidualna. Widać więc wyraźnie, że gdy rzymski filozof pisze o pojęciu osoby, to nie opisuje jej za pomocą terminu ousia, lecz - hypostasis. Niestety, jak się później okazało, filozofowie komentujący Boecjusza przeoczyli to rozróżnienie.

${ }^{19}$ A. Kijewska, Boecjusz..., dz. cyt., s. 48.

${ }^{20}$ Zob. Boecjusz, Księga o osobie i dwóch naturach przeciwko Eutychesowi i Nestoriuszowi do Jana, Diakona Kościoła Rzymskiego, [w:] O pociechach filozofii ksiag pięcioro oraz traktaty teologiczne, Altaya Polska, Poznań 1926, s. 227. 
Faktem jest, że klasyczna definicja osoby, która w etyce i filozofii odgrywała i odgrywa nadal ważną rolę, powstała na gruncie sporów trynitarnych i chrystologicznych. Była określeniem stricte teologicznym, mającym umożliwić albo przynajmniej pomóc w zrozumieniu tajemnicy Trójcy Świętej i tego, jak Chrystus może być jedną osobą w dwóch naturach. Definicja ta nie miała więc charakteru czysto filozoficznego, ani - co oczywiste etycznego.

Dlaczego warto w ogóle zagłębiać się w dyskusje teologiczne? Powody ku temu są dwa. Po pierwsze, bardzo ważne, by uświadomić sobie, że pojęcie osoby ma bogatą i niezwykle interesującą historię. Dzieje ewolucji tego terminu w teologii są wręcz zadziwiające. Po drugie, już w okresie średniowiecza status pojęcia osoby był różny w zależności od tego, czy funkcjonowało ono w języku sztuki, siatce pojęciowej prawa cywilnego czy (last but not least) w teologii. Każde z tych trzech przywołanych znaczeń wykształciło się w innych warunkach i siatkach pojęciowych. Każda z „osób” pełniła inne funkcje. Można z dużą dozą prawdopodobieństwa założyć, że wszelkie próby znalezienia wspólnej istoty tych trzech definicji nie mogą się powieść. W tym miejscu należy zawiesić rozważania i przyjrzeć się bliżej dyskusjom filozoficznym.

2.4. Osoba W Filozofit. Jedna Zagadia - Wiele RoZW I Ą Z A Ń. Na przestrzeni wieków próbowano zmierzyć się z problematyką „osoby” wielokrotnie. Kartezjusz, John Locke, David Hume, Immanuel Kant, Daniel Dennett, Peter Strawson, Ludwig Wittgenstein, dwudziestowieczni filozofowie dialogu - to tylko niektóre przykłady, które zapisały się w historii filozoficznych badań nad tym pojęciem. Przy uwzględnieniu celów artykułu istotne są jedynie te koncepcje, które wnoszą nową jakość do dyskusji związanych z naturą „osoby”.

Pierwszą omawianą teorią jest propozycja Johna Locke'a, która w literaturze przedmiotu nosi nazwę koncepcji psychologicznej. Druga to etyczna definicja osoby Immanuela Kanta. Krótko scharakteryzowana zostanie także dwudziestowieczna dyskusja poświęcona interesującemu nas zagadnieniu. Kryterium wyboru tych definicji spośród wielu możliwych jest częściowo arbitralne, ale - nie całkowicie. Oprócz klasycznej definicji Boecjusza, koncepcje Kanta i Locke'a uważane są za paradygmatyczne ze względu na pewne ich cechy i sposób ujęcia tematu. Mówiąc o osobie w filozofii musimy za każdym razem zaznaczyć, którą z wielu wypracowanych teorii mamy 
na myśli, ponieważ problem istnienia osoby, jej opisu, wyznaczenia kryteriów odróżnienia osób od nie-osób, był przez wieki szeroko dyskutowany. Z powodu wielości koncepcji pojawił się szereg interesujących i porządkujących podziałów.

Po pierwsze, koncepcje osoby dzielimy na: deskryptywne (metafizyczne) i aksjologiczne (moralne). Definicje deskryptywne skupiają się na opisie, czym jest definiowany przedmiot, czyli w tym przypadku: jakie elementy muszą wystąpić, by można było mówić o osobie; jakie są kryteria jej tożsamości; do jakich empirycznych elementów należy się odnieść, chcąc ją zidentyfikować. Z kolei aksjologiczne (moralne) definicje osoby skupiają się, mówiąc ogólnie, na osobie jako nośniku wartości.

Drugim podziałem, który porządkuje definicje deskryptywne, jest podział teorii osoby na teorie substancjalne i teorie wiązki ${ }^{21}$. Te pierwsze zakładają istnienie trwałej podstawy, czegoś, co decyduje o tożsamości, ciągłości w czasie bytu osobowego; właśnie to „coś” jest istotą osoby. Osoba w teoriach substancjalnych nie jest zbiorem pewnych procesów mentalnych czy psychofizycznych, ale stanowi rodzaj jakiegoś bytu trwale istniejącego o konkretnych właściwościach. Do substancjalnych teorii zaliczane są takie koncepcje, jak klasyczna definicja Boecjusza, ego cogitans Kartezjusza, psychologiczna teoria Locke'a, a także propozycje innych autorów, jak choćby: Rodericka Chisholma, Geoffrey'a Madella czy Johna McTaggarta.

Teorie wiązki inaczej ujmują problematykę osoby. Ich zwolennicy nie widzą sensu w poszukiwaniach substancjalnej podstawy, warunkującej tożsamość w czasie. Innymi słowy, zgodnie z teoriami wiązki osoby stanowią serię stanów mentalnych, procesów powiązanych między sobą różnymi relacjami. Za pierwszego filozofa, którego można nazwać zwolennikiem teorii wiązki, uważa się Davida Hume'a. Współcześnie ten rodzaj refleksji nad osobą prowadzi między innymi Derek Parfit ${ }^{22}$.

2.5. Psychologiczna Koncepcja osoby John'a Locke'a. Pojęcie osoby wypracowane przez angielskiego empirystę Johna Locke'a miało znaczący wpływ na późniejsze propozycje filozoficzne. Ważne jest

${ }^{21}$ Zob. C.O. Evans, The Subject of Consciouness, George Allen \& Unwin Ltd, Humanities Press Inc., Londyn, Nowy Jork 1970, s. 26-36; L. Stubenberg, Consciousness and Qualia, Amsterdam, John Benjamins Publishing Company, Amsterdam 1998, s. 276-277.

${ }^{22}$ Zob. D. Parfit, Reasons and Persons, OUP, Oxford 1984. 
również to, że właśnie Locke jest uznawany za pierwszego filozofa, który rozważając pojęcie osoby podał wyraźne kryteria, za pomocą których można odróżnić osoby od nie-osób:

Na przestrzeni wieków konieczne i wystarczające warunki, jakie musiała spełnić osoba, były proponowane przez różnych filozofów. John Locke jest punktem odniesienia dla każdej analizy filozoficznej pojęcia osoby, ponieważ wydaje się, że jest pierwszym, który wyraźnie powiedział, co rozumie pod tym pojęciem ${ }^{23}$.

To jasno sformułowane kryteria i wyraźna definicja sprawiają, że zasięg oddziaływania propozycji Locke'a objął teorie najznamienitszych filozofów dziewiętnastego wieku i liczne grono dwudziestowiecznych myślicieli. Co więcej, pojęcie osoby w rozumieniu Locke'owskim zaczyna odgrywać współcześnie ważną rolę w dyskusjach bioetycznych, tym samym posługiwanie się nim może mieć konsekwencje, których jego autor nie był w stanie przewidzieć.

Uwagi o inspirującym charakterze teorii Locke'a nie oznaczają oczywiście jej powszechnej akceptacji - zwłaszcza że koncepcja ta jest elementem szerszej teorii filozoficznej i wynika z jej podstawowych założeń. Wystarczy, że przyjmiemy inne założenia, a Locke'owskie pojęcie osoby będzie nie do utrzymania. Skądinąd inni myśliciele - mimo odmiennych założeń filozoficznych - postanowili wykorzystać intuicje Locke'a. Filozofowie tacy jak Hume czy Parfit nawiązując do myśli Locke'a rozwijają koncepcje osoby w zupełnie nowym kierunku. Podobnie czyni Immanuel Kant, dla którego teoria psychologiczna stanowiła punkt wyjścia w jego własnych rozważaniach związanych z koncepcją osoby.

Locke proponuje dwa rozumienia pojęcia osoby. Pierwsze, zwane w literaturze przedmiotu „metafizycznym”, odpowiada na pytanie: czym osoba jest? Drugie, zwane „prawnym znaczeniem osoby”, wyjaśnia, w jaki sposób

${ }^{23}$ "Over the centuries, necessary and sufficient conditions for personhood have been laid out by various philosophers. John Locke is usually the starting place for any serious philosophical study of the concept of personhood because he seems to be the first to make explicit what he meant by the term": M.F. Goodman, Personhood, [w:] D.M. Borchert, Encyclopedia of Philosophy, Macmillan Reference USA, Detroit 2006, nr 7, s. 238, przekład własny - R.Z. 
pojęcie osoby jest przydatne w naukach normatywnych. Założeniem, które Locke przyjmuje na początku swoich rozważań, jest istnienie zasadniczej różnicy pomiędzy „człowiekiem” i „osobą”. Zgodnie z przyjętą przezeń metodologią badał pojęcia tak, jak jawią się one w umyśle (element psychologiczny), następnie rozkładając je na czynniki pierwsze (element analityczny). Te dwa zabiegi miały pomóc w wyjaśnieniu konkretnego pojęcia, uchwyceniu jasnej idei. Zgodnie z tym schematem, przyjął, że:

Oznacza on [termin „osoba” - dop. R.Z.], moim zdaniem, istotę myślącą i inteligentną, obdarzoną rozumem i zdolnością do refleksji, istotę, która może ujmować siebie myślą jako samą siebie, to znaczy jako tę samą w różnych czasach i miejscach myślącą rzecz ${ }^{24}$.

Osoba dla Locke'a to byt racjonalny, samoświadomy oraz tożsamy. To właśnie ta ostatnia cecha, czyli tożsamość osoby, stanowiła główny cel dociekań angielskiego filozofa. Zdaniem Locke’a każdy rodzaj bytu ma własne kryteria tożsamości. Poświęćmy jej więc nieco więcej uwagi.

Osoba może ujmować samą siebie na dwa sposoby: pierwszy, czyli ujmowanie siebie samej $\mathrm{w}$ danej chwili, jest warunkiem tożsamości synchronicznej, warunkującej bycie sobą w określonej chwili. Drugim sposobem pojmowania siebie samego jest rozpoznawanie siebie $w$ czasie $t_{1} i_{2}$. Jak pisze Józef Bremer:

Locke podkreśla, że istotną cechą osoby jest ciągłość, posiadająca wewnętrzny wymiar zwany świadomością. Bycie świadomym oznacza, że podmiot obejmuje siebie jako „tę samą myślącą istotę"25.

Ważnym elementem tak rozumianej świadomości osoby jest pamięć. Bycie świadomym przeżyć przeszłych pozwala stwierdzić, że określone sytuacje przydarzyły się właśnie jej. Tego rodzaju propozycje mają jednak swoje konsekwencje. Utrata pamięci stanowi utratę osobowości. W takiej sytuacji mamy do czynienia z dwiema osobami - jedną sprzed utraty pamięci i drugą powstałą po tej utracie. Wynika z tego, że dla Locke'a osoba wiąże

\footnotetext{
${ }^{24}$ J. Locke, Rozważania dotyczace rozumu ludzkiego, PWN, Warszawa 1955, s. 471.

${ }^{25} \mathrm{~J}$. Bremer, Osoba - fikcja czy rzeczywistość. Tożsamość i jedność Ja w świetle badań neurologicznych, Aureus, Kraków 2008, s. 168.
} 
się przede wszystkim z ciągłą tożsamością samowiedzy. Takie jej rozumienie różni się od pojęcia człowieka, dla którego kryteria tożsamości są zgoła odmienne.

Zdaniem Locke’a idea człowieka oznacza organizm, funkcjonujące ciało. Tożsamość człowieka jest związana z tożsamością istot żywych, z ich „wewnętrzną zasadą organizacji”. Warunkiem istnienia człowieka jest ciągłość w jego biologicznym funkcjonowaniu. Dlatego możemy powiedzieć, że płód ludzki, z którego potem wyrasta dorosły człowiek, to ciągle ten sam człowiek. Podsumowując kwestię tożsamości - z jedną i tą samą osobą mamy do czynienia, gdy występuje nieprzerwana ciągłość samowiedzy. Osoba musi być świadoma swoich przeszłych i teraźniejszych czynów jako takich, których ona jest autorem.

Z kolei w przypadku człowieka kryterium tożsamości jest zasadniczo prostsze, aczkolwiek niekoniecznie łatwiejsze do zastosowania - mianowicie powiązanie tożsamości człowieka $\mathrm{z}$ wewnętrzną zasadą organizacji istot żywych wydaje się wprowadzone trochę na siłę. Na pewno kryterium tego nie nazwalibyśmy intuicyjnym. Rozwiązanie problemu tożsamości zaproponowane przez Locke'a jest także krytykowane za pewne niekonsekwencje, które pojawiają się podczas posługiwania się nim w dyskursie filozoficznym.

Przede wszystkim ich wprowadzenie jest kontrintuicyjnym opisem człowieka i osoby. W języku potocznym człowiek i osoba to pojęcia funkcjonujące zamiennie. Oznaczać by to mogło, że podana ich charakterystyka nie jest właściwym odszyfrowaniem tego, co kryje się za tymi dwoma pojęciami. Sprawa komplikuje się jeszcze bardziej, gdy wprowadzimy prawnicze rozumienie pojęcia osoby. Osoba w takim ujęciu jest bytem rozumnym, zdolnym do działania, odczuwania szczęścia, a przede wszystkim - do podlegania prawu:

Etyczne znaczenie czynów osoby wiąże się z jej świadomością i samoświadomością. Tożsamość osobowa (tożsamość świadomości) jest więc wystarczającym i koniecznym warunkiem pociągnięcia kogoś do odpowiedzialności za jego czyny ${ }^{26}$.

\footnotetext{
${ }^{26}$ Tamże, s. 175.
} 
Przyjrzymy się bliżej temu stwierdzeniu, zwłaszcza pod kątem praktycznych skutków, będących efektem przyjęcia powyższych tez Locke'a. Akceptacja twierdzenia, że tylko osoby mogą być pociągane do odpowiedzialności za swoje czyny, powoduje, że pamięć własnych czynów (jako własnych!) jest warunkiem przypisania odpowiedzialności. Co więcej, warunkiem takim jednocześnie staje się ciągłość samowiedzy („wiem, że ja to właśnie ja”). Nie jest to jednak jedyny warunek przypisania odpowiedzialności prawnej, co na bazie powyższych założeń bynajmniej nie wydaje się oczywiste. Innym warunkiem przypisania odpowiedzialności jest fizyczna obecność na miejscu zbrodni. U Locke'a jednak kryterium obecności wcale nie musi być spełnione:

Zgodnie z myślą Locke’a oczywistym jest, że ludzie są odpowiedzialni za swoje czyny, wtedy gdy są je w stanie rozpoznać jako ich własne działanie. To twierdzenie oznacza dwie rzeczy: po pierwsze, świadomość że gdy ktoś coś robi, wie że to robi, i po drugie, zdolność do pamiętania tego, co się zrobiło. Tym samym, powiada Locke, kryterium identyczności osób, różnym od człowieka, jest świadomość, pojęcie, które łączy uwagę (awareness) i pamięć. Fakt, że ten sam człowiek staje przed nami, nie oznacza, że to jest ta sama osoba, skoro człowiek może nie być świadomy uczynienia czegoś, a jeżeli człowiek nie jest świadomy, to ta osoba tego nie zrobiła ${ }^{27}$.

Paradoksalnie wystarczy, żeby osoba była przeświadczona o tym, że dokonała zbrodni (bez fizycznej obecności na miejscu zdarzenia), by przypisać jej odpowiedzialność. Niestety zgodnie z przyjętymi założeniami o tożsamości jakiegoś bytu decyduje jedno i tylko jedno kryterium. Przyjęcie dwóch kryteriów tożsamości osoby prawnej (kryterium „psychiczne” i „fizyczne”) sugerowałoby, że osoba rozumiana na sposób prawniczy nie jest jednym

${ }^{27}$ „He thought it obvious that what makes people accountable for their actions is their ability to recognize them as their own. This seems to mean two things: first, an awareness of what one is doing when one is doing it and, second, an ability to remember having done it. Hence, he said that the criterion for the identity of persons, as distinct from men, is consciousness, a concept intended to embrace both awareness and memory. The fact that the same man is before us does not mean that the same person is, since the man may not be conscious of having done the deed in question and if the man is not conscious of having done it, then the person did not do it": T. Penelhum, Personal Identity, [w:] D.M. Borchert, Encyclopedia..., dz. cyt., s. 216, przekład własny - R.Z. 
bytem, ale złożeniem dwóch różnych. Dzisiaj wydaje się czymś trywialnym stwierdzenie, że przyznanie się do winy wcale nie musi kończyć postępowania przed sądem. Przeprowadzane są czynności procesowe, które abstrahując od przeświadczeń podejrzanego, mają za zadanie wykazać, kto faktycznie dopuścił się czynu zabronionego. Zakładając nawet, że konkretna osoba (rozumiana na sposób Locke'owski) doskonale pamięta, że popełniła dany czyn, i szczerze się do niego przyznaje, wyznanie takie nie jest rozstrzygające, ponieważ innym problemem, nad którym angielski filozof przeszedł do porządku dziennego, jest kwestia pamięci zdarzeń przeszłych, tak istotna dla tożsamości osoby.

Czasownik „pamiętać” funkcjonuje w mocnym i słabym sensie. Gdy mamy na myśli mocny sens czasownika „pamiętać”, zakładamy jednocześnie poprawność wspomnień. Jeżeli więc powiemy, że ktoś nie pamięta, to w mocnym sensie zwrot taki oznacza, że danej jednostce tylko wydaje się, iż pamięta określone zdarzenia. W słabym sensie, gdy mówimy, że ktoś pamięta, to oznacza, iż jest szczerze przekonany, że pamięta ${ }^{28}$. Zważywszy na rolę pamięci w teorii osoby Locke'a, warto zastanowić się nad jej użytecznością w opisie ciągłości tożsamości osoby. By można było wydać sąd o tym, że Kowalski jest tą samą osobą, która widziała X, musi on pamiętać to wydarzenie (w mocnym sensie czasownika „pamiętać”). W takim razie musimy dysponować pewnym mechanizmem rozróżniania wspomnień w mocnym sensie od wspomnień w słabym sensie. Wprowadzenie pamięci jako warunku tożsamości osoby w sposób, jaki czyni to Locke w swojej koncepcji, nie tylko nie rozwiązuje problemów, co raczej generuje nowe.

Na koniec analizy teorii psychologicznej warto wrócić do pierwszej kwestii, od której Locke zaczyna swoje rozważania, mianowicie od rozróżnienia idei człowieka i idei osoby. Podział na biologicznie funkcjonujące ciało i myślącą substancję, o której Locke zgodnie z założeniami swojej filozofii nie może pisać, nasuwa myśl, że angielski filozof tworzy swoją teorię w paradygmacie kartezjańskim. Oczywiście nie mówi wprost o istnieniu dwóch substancji: rozciągłej i duchowej, ale wiele z jego uwag wskazuje, że pisząc o osobie i człowieku Locke skłania się ku temu podziałowi.

${ }^{28}$ Por. A. Flew, Locke and the Problem of Personal Identity, „Philosophy” 1951, nr 26, s. 53-68; J. Butler, of Personal Identity, [w:] The Analogy of Religion, red. W.E. Gladstone, OUP, Oxford 1897, nr 1, s. 385 i n. 
Na poparcie tej tezy wystarczy przypomnieć o dwóch kryteriach tożsamości właściwych dla człowieka i osoby oraz o założeniu, że jedno kryterium przysługuje jednemu rodzajowi bytu. Jednakże paradygmat kartezjański nie jest propozycją przyjmowaną bezkrytycznie. Zwłaszcza dzisiaj, w świetle osiągnięć nauk neurobiologicznych.

Podsumowując model osoby Johna Locke'a, należy zaznaczyć, że pomimo pozornej jasności sformułowania tez, jest on obarczony licznymi nieścisłościami i niekonsekwencjami. Nie wydaje się, by był on odpowiednim opisem tego, co chcemy nazywać osobą.

2.6. ETYCZNA KONCEPCJA KANTA. Kolejna koncepcja osoby, zwana „koncepcją etyczną", została opracowana przez Immanuela Kanta. Jego definicja jest bardzo mocno uwikłana w transcendentalny system filozoficzny. Nie czas i miejsce, by przywoływać szczegółową argumentację, której efektem są poszczególne elementy definicji osoby. Mówiąc ogólnie, Kant odrzuca definicję osoby jako ego cogitans:

\begin{abstract}
Nie można [o 'Ja'] nawet powiedzieć, że jest pojęciem, lecz jedynie, że jest samą tylko świadomością towarzyszącą wszelkim pojęciom. Przez owo Ja, On lub Ona, które myśli, nie przedstawimy sobie nic więcej jak tylko transcendentalny podmiot myśli = x, który poznajemy jedynie poprzez myśli stanowiące jego określenia; o nim samym w odosobnieniu nie możemy mieć nawet najmniejszego pojęcia. Krążymy więc stale dookoła niego, albowiem by cokolwiek o nim sądzić, musimy już zawsze rozporządzać jego przedstawieniem ${ }^{29}$.
\end{abstract}

Kantowskie rozróżnienie na rozum teoretyczny i praktyczny nie pozostaje - jak widać - bez wpływu na definicję osoby. Na gruncie rozumu teoretycznego nie mamy niczego takiego jak przedstawienie osoby. Jak pisze Bremer: „nie ma tutaj psychologicznego opisu, osobistej historii, ujęcia Selbst jako przedmiotu mającego takie a takie cechy"30. Kant w kontekście swej transcendentalnej filozofii odrzuca tradycję kartezjańską, a wraz z nią także Locke'owską koncepcję osoby. Kantowska krytyka metafizyki, zgodnie z którą idea duszy jest jedną z trzech idei regulatywnych organizujących poszczególne działy doświadczenia, dowodzi, że na gruncie rozumu

\footnotetext{
${ }^{29}$ I. Kant, Krytyka czystego rozumu, PWN, Warszawa 1957, s. 55.

${ }^{30}$ J. Bremer, Osoba..., dz. cyt., s. 236.
} 
teoretycznego nie można stworzyć koncepcji osoby. Jednakże metafizyka osoby jest możliwa na gruncie rozumu praktycznego. Można by w tym miejscu przywołać więcej fragmentów z dzieł Kanta, jednakże wszystkie presuponują wizję osoby, zgodnie z którą osobę definiuje jej odpowiedzialność za własne czyny. Jest ona elementem szerszej siatki pojęciowej Kantowskiej filozofii moralnej.

Etyczna definicja osoby jest czymś zasadniczo różnym od klasycznej i psychologicznej. Nic dziwnego, każda z tych trzech wpływowych koncepcji powstawała w kontekście różnych założeń. Boecjusz pisząc o pojęciu osoby pozostawał pod wpływem metafizyki Arystotelesowskiej. Jego celem zresztą nigdy nie były ani rozważania etyczne, ani stricte filozoficzne, ale analizy z zakresu teologii trynitarnej. Locke pisząc swój An Essay Concerning Human Understanding pozostawał pod silnym wpływem paradygmatu kartezjańskiego, z jego podziałem na dwie substancje i z wszystkimi tego konsekwencjami. Z kolei etyczna koncepcja osoby jest mocno zakorzeniona $\mathrm{w}$ transcendentalnej filozofii Kanta. Trudno więc nawet porównywać ze sobą klasyczną, psychologiczną i etyczną definicję osoby.

\section{WNIOSKI}

Na zakończenie tej części pracy odnotujmy kilka faktów. Po pierwsze, definicje osoby wypracowane w filozofii przez różnych autorów nie mogą być wykorzystywane ad hoc, w oderwaniu od ich filozoficznego (czy teologicznego) kontekstu. Żadna z definicji nie jest tworzona w próżni, każda opiera się na pewnym systemie pojęciowym: klasyczna znajduje oparcie $\mathrm{w}$ arystotelizmie, psychologiczna utrzymana jest w tradycji kartezjańskiej, a etyczna wyrasta z transcendentalnej filozofii Kanta.

Znalezienie filozoficznych „transformacji Lorentza" dla pojęcia osoby, które umożliwiałyby płynne przechodzenie pomiędzy tymi trzema „osobami”, wydaje się niemożliwe. Z kolei dwudziesty wiek stanowi erupcję nowych, analitycznych i naturalistycznych ujęć podmiotu, w dużej części niepokrywających się ze sobą. Wydaje się, że - w ramach filozofii, a zwłaszcza etyki - „osoba” jest pojęciem wieloznacznym, nieredukowalnym do jednej ogólnej definicji. Dlatego wybór definicji jest z konieczności częściowo arbitralny. Filozofia nie daje nam prostego rozwiązania zagadki "osoby". 


\section{NEUROBIOLOGICZNA KONCEPCJA OSOBY}

Po powyższych analizach przyszła kolej na prześledzenie odpowiedzi neurobiologów na pytanie, czym jest osoba. Możemy odnaleźć liczne próby zbudowania naturalistycznych koncepcji osoby, zwłaszcza gdy przyjrzymy się filozofom szukającym odpowiedzi na gruncie neurobiologii. W tej części pracy zaprezentuję jednak koncepcję tylko jednego autora - Josepha LeDouxa, który w książce Synaptic Self: How Our Brains Become Who We Are $e^{31}$ próbuje odpowiedzieć na pytanie, w jaki sposób badania nad mózgiem mogą pomóc nam w zrozumieniu tego, czym jest osoba. LeDoux postawił ten problem (przynajmniej początkowo) wprost. Autor Synaptic Self oczywiście zdaje sobie sprawę ze złożoności kwestii, której zbadania się podjął:

Obecnie dostępna jest dość duża ilość informacji dotyczących sposobu funkcjonowania mózgu, i gdy na tę chwilę nie jest ich jeszcze wystarczająco wiele, by wyjaśnić osoby, to powinny nas one motywować do rozpoczęcia prac nad tym zagadnieniem ${ }^{32}$.

W tym duchu amerykański neurobiolog zaczyna analizować procesy zachodzące w mózgu, które mają wyjaśnić, jacy jesteśmy. Mówiąc bardziej precyzyjnie, gdy LeDoux pyta o pojęcie osoby oraz o możliwość zdefiniowania go na gruncie nauk neurobiologicznych, to po pierwsze przeformułowuje ten problem na inne pytanie; mianowicie zastanawia się, co czyni nas takimi, jacy jesteśmy. Ta delikatna zmiana w sposobie postawienia pytania z: „kim są osoby?” na: „co sprawa, że jesteśmy, jacy jesteśmy?” może wydawać się nieistotna. Jednakże - zważywszy na to, że uwagi dotyczące terminologii, której LeDoux używa, pojawiają się na pierwszych kartach książki wydaje się, że przez to książka zmienia trochę przedmiot swego dociekania.

\footnotetext{
${ }^{31}$ J. LeDoux, Synaptic Self: How Our Brains Become Who We Are, Viking Adult, Nowy Jork 2002.

${ }^{32}$ "A lot of information is available about how the brain works, and while it may not yet be sufficient to fully explain persons, it should certainly encourage us to begin thinking about the problem": tamże, s. 1.
} 
Kolejną istotną zmianą pojęciową, której LeDoux dokonuje, jest utożsamienie pojęcia osoby/osobowości z pojęciem self ${ }^{3}$.

Nie ma potrzeby, aby w tym miejscu rekonstruować rozbudowane analizy LeDouxa ze wszystkimi szczegółami. Przyjrzymy się tutaj jedynie wybranym uwagom, które można odnaleźć w Synaptic Self. Autor jest świadomy różnic pomiędzy charakterem stawianych problemów i sposobami ich rozwiązywania na gruncie filozofii i neurobiologii. Dlatego zdaje sobie sprawę, że jego definicja osoby - przeformułowana na język nauk biologicznych niekoniecznie musi odpowiedzieć na pytania stawiane przez filozofów ${ }^{34}$. Dywagacje nad tym, czy osoba jest czymś cielesnym, częściowo cielesnym, częściowo mentalnym, a może całkowicie duchowym, nie mają znaczenia w kontekście neurobiologicznego pytania o osobę, postawionego $\mathrm{w}$ taki sposób, jak robi to LeDoux. Nie przybliżają nas one do wyjaśnienia mechanizmów w mózgu, które sprawiają, że jesteśmy tym, kim jesteśmy. LeDoux, jak każdy neurobiolog, przyjmuje założenie, że wyjaśnienie materialistyczne jest poprawne, a dopiero potem zaczyna szukać dowodów na potwierdzenie swojej tezy.

Jedyne, co można zrobić w takiej sytuacji, to zostawić dylematy filozoficzne i skoncentrować się na budowaniu definicji jaźni w terminach neuronalnych. Sam tytuł dzieła Synaptic Self wskazuje na częściową rezygnację

${ }^{33}$ „[...] it's that your „self” the essence of who you are, reflects patterns of interconnectivity between neurons in your brain. Connections between neurons, known as synapses, are the main channels of information flow and storage in the brain. Most of what the brain does is accomplished by synaptic transmission between neurons, and by calling upon the information encoded by past transmission across synapses. Given the importance of synaptic transmission in brain function, it should practically be a truism to say that the self is synaptic. What else could it be?": tamże, s. 2 .

${ }^{34}$ Ale może. Na przykład utożsamienie umysłu, jaźni, osoby z procesami świadomymi jest błędem, ponieważ znaczna ilość czynności związanych z ocenianiem, wydawaniem sądów etc. związana jest z procesami znajdującymi się w starszych ewolucyjnie częściach mózgu, których praca przebiega poza świadomością i czasem nigdy do świadomości nie dociera. Kartezjusz, jak zauważa LeDoux, utożsamiał procesy nieświadome z substancją cielesną. Tego, czego LeDoux nie rozumie, to dlaczego filozof przypisał świadomość substancji niecielesnej. Wydaje się, że - w pewnym stopniu - odkrycia na gruncie neuronauki mogą falsyfikować niektóre tezy filozoficzne. 
z pojęcia osoby. Co więcej, główna idea przyświecająca książce LeDouxa, czyli wytłumaczenie mechanizmów ukrytych w mózgu, które odpowiedzialne są za to, kim jest każdy z osobna w swojej wyjątkowości, prowadzi do wniosku, że jaźń jest strukturą czysto synaptyczną.

Problem osoby $\mathrm{w}$ neurobiologii to problem nowego, pogłębionego rozumienia człowieka. Jest związany z takimi kwestiami, jak: w jaki sposób wykształca się indywidualność, zdolność do samoodniesienia, jakie interakcje na poziomie neuronalnym zachodzą pomiędzy systemami odpowiedzialnymi za funkcje poznawcze, emocje i motywacje. Właśnie w tych relacjach znajduje się odpowiedź nie na pytanie: kim my jesteśmy, ale na pytanie: jak człowiek funkcjonuje.

Tego typu prace prowadzą raczej do uzyskania nowej wizji człowieka, poprzez poznanie mechanizmów odpowiadających za myślenie, odczuwanie emocji i procesy motywacyjne. To wszystko pozwola lepiej poznać człowieka. Pozostaje jednak pytanie: czy to, czego się dowiemy, pozwoli nam lepiej zrozumieć „osobę”?

Szukanie odpowiedzi na pytanie o osobę u neurobiologa jest bardzo podobne do zapytywania kosmologa, czy istnieje Bóg. Kosmolog - będąc naukowcem - nie odpowie na to pytanie wprost; jego praca polega na odkrywaniu najgłębszych struktur rzeczywistości za pomocą skomplikowanych narzędzi matematycznych. Czy poznanie świata przybliża nas do poznania Boga? Nie. Czy wyrafinowane struktury świata wskazują na coś niemieszczącego się w sferze racjonalności matematycznej? Być może. Ale to, co jest najważniejsze w kosmologii, to fakt, że dostarcza nam ona nowego i coraz bardziej fascynującego obrazu rzeczywistości.

Analogicznie sytuacja kształtuje się z pytaniem o osobę na gruncie neurobiologii. Neurobiolog takie pytanie od razu będzie się starał przeformułować, najpierw na problem jaźni, potem na problem dwóch rodzajów jaźni (explicit i implicit), w końcu na problem mózgu i jego struktury; najpierw ogólnej, aż w końcu poprzez badanie neuronów (synaps) dojdziemy do poziomu molekularnego. Odpowiedź, której możemy się spodziewać od neurobiologa, będzie udzielona w terminach naukowych; od przyjętej przez nas interpretacji będzie zależeć, czy wynik jego badań nad funkcjonowaniem mózgu nazwiemy koncepcją osoby. 


\section{STATUS POJĘCIA OSOBY. PODSTAWOWE PROBLEMY}

Ze szczególnym statusem pojęcia osoby wiąże się szereg podstawowych problemów, które czasem skutkują pojawieniem się postulatów o nieposługiwanie się tym pojęciem, zwłaszcza gdy jego niewłaściwe użycie mogłoby prowadzić do szkodliwych konsekwencji praktycznych. Jedna z propozycji tego typu, autorstwa Berta Gordijna, pojawiła się na gruncie bioetyki. Gordijn uważa, że:

Te za 1: Pojęcie osoby ma fundamentalne znaczenie dla schematu pojęciowego bioetyki. Pomimo że powoduje więcej problemów, niż rozwiązuje.

T e za 2: Znaczenie tego terminu nie jest do końca jasne. Na płaszczyźnie praktycznej ta niepewność terminologiczna sprawia, że w konkretnych sytuacjach nie wiadomo, kogo można uznać za osobę, a kto osobą już nie jest.

T e z a 3 : Pojęcie osoby wprowadza nadmierne uproszczenia w rozważaniach bioetycznych. Pełni rolę pojęcia-zaklęcia, które ukrywa luki w naszej wiedzy.

T e za 4: Rezygnacja z pojęcia osoby może zwiększyć przejrzystość $\mathrm{i}$ - przede wszystkim - jakość dyskusji bioetycznych ${ }^{35}$.

Gordijn odnotowuje, że w dyskursie filozoficznym mamy do czynienia z dwoma stanowiskami. Pierwszym, którego przedstawiciele konstruują deskryptywne definicje osoby, oraz drugim, w ramach którego osoba ma pewną wartość aksjologiczną, a więc staje się nośnikiem wartości, podmiotem praw i obowiązków, moralnym agentem. Trudności pojawiają się wtedy, gdy w dyskusjach bioetycznych zaczyna się przyznawać pewne prawa jednostkom, definiowanym jako osoby, i jednocześnie odmawia się ich nie-osobom. Pojawia się wtedy pytanie: czy wybrana definicja osoby jest tą właściwą? Jeżeli tak, na jakiej postawie się tak twierdzi? Jeżeli nie, w jaki sposób można odnaleźć „właściwe” kryterium?

Innym argumentem, jaki przedstawia Gordijn, jest tak zwany argument z ekonomiki myślenia. Jeżeli - tak jak to się dzieje w przypadku większości definicji deskryptywnych - osoba rozumiana jest jako zbiór pewnych cech,

${ }^{35}$ B. Gordijn, The Troublesome Concept of the Person, „Theoretical Medicine and Bioethics” 1999, nr 20, s. 347-359. 
to (zgodnie z zasadą brzytwy Ockhama) nie potrzebujemy posługiwać się odrębnym pojęciem osoby, a musimy jedynie skupić się na badaniu, czy dany człowiek w konkretnej sytuacji posiada określoną cechę (np. w przypadku aborcji, gdy osobę utożsamiamy z podmiotem zdolnym do samoodniesienia, nie należy zastanawić się, czy dany płód jest osobą, ale: czy posiada daną zdolność). Oczywiście tego rodzaju zabieg nie powoduje rozwiązania istniejących i przyszłych dylematów bioetycznych, ale - zdaniem Gordijna - uwalnia je od niejasności związanych z pojęciem osoby ${ }^{36}$.

Drugi argument ma podobny charakter, choć może nie jest tak mocny, ponieważ dotyczy ,jedynie” trudności technicznych. Mianowicie jeżeli liczba cech, które dany człowiek musi posiadać, by zyskać miano osoby, jest stosunkowo duża, wówczas pojęcie to wcale nie przybliża nas do lepszego zrozumienia się nawzajem, a tym samym brak mu praktycznych zastosowań i staje się ono bezużyteczne. Oczywiście ten argument ma swoje źródło w problemie opisywanym powyżej.

Trzeci argument nawiązuje do natury problemów moralnych. Innymi słowy, pojęcie osoby wprowadza czarno-białą wizję świata i ostre podziały w dyskusjach etycznych. Posługiwanie się jednoznacznymi rozróżnieniami w przypisywaniu podmiotowości moralnej (X jest osobą, więc przysługują mu wszystkie prawa, Y nie jest osobą więc prawa mu nie przysługują) sugeruje fałszywą jasność i łatwość rozstrzygania problemów ze sfery moralnej. Gordijn twierdzi, że sfera normatywna jest o wiele bardziej skomplikowana i nie można posługiwać się tak prostym kluczem jak: „osoba”/,nie-osoba” w legitymizowaniu sądów etycznych. Opuszczenie tego terminu w dyskusjach bioetycznych nie spowoduje oczywiście rozwiązania problemów, ale umożliwi prowadzenie debat etycznych na mniej ogólnym poziomie, dzięki czemu zyskają one na precyzji ${ }^{37}$.

\footnotetext{
${ }^{36}$ Tamże.
}

${ }^{37}$ "In the debate on the moral status of the fetus, for instance, the following questions could be discussed without using the concept of the person: What is the moral significance of conception and nidation? How does the commencement of the nervous system influence the moral status of the fetus? Does the completion of the embryogenesis or the ability to survive independently of the body of the mother change the set of moral attributes of the unborn? What is the moral meaning of birth? What, if any, are the moral implications of being a human fetus instead of, for example, a chimpanzee fetus? Can a difference in moral status of the fetus be justified on the basis 
Podobne wnioski możemy odnaleźć w pracach poświęconych problemom powstającym na styku filozofii, etyki i neuronauk. Martha Farah i Andrea Heberlein ${ }^{38}$, autorki prac z zakresu neuronauki, idą w swoich rozważaniach dalej niż filozofowie i etycy. Sugerują, że odpowiedzi na nasze wątpliwości możemy znaleźć - albo przynajmniej zacząć szukać - na gruncie nauk przyrodniczych ${ }^{39}$.

Program badawczy, którego celem jest znalezienie „naturalnych” korelatów „osoby”, miałby polegać na ustaleniu kryteriów pozwalających odróżnić osoby od nie-osób na podstawie danych biologicznych. Co więcej, takie kryteria powinny być zgodne z powszechnie podzielanymi intuicjami odnoszącymi się do pojęcia osoby. Pojawia się tutaj jedna wątpliwość: w jaki sposób uda nam się zbudować spójny model osoby, mający za podstawę potoczne przekonania, a następnie porównać ten model z osiągnięciami z zakresu nauk biologicznych? Inna wątpliwość, która pojawia się w tym miejscu, dotyczy kwestii: według jakich kryteriów zdecydowano się na wybór tak zwanej folk defnition, a nie innego, filozoficznie opracowanego modelu osoby? Czy arbitralność, z którą dane pozyskane dzięki osiągnięciom nauk przyrodniczych planowano usunąć, nie pojawia się już na etapie selekcji odpowiednich danych biologicznych, mających wspierać arbitralnie wybraną wizję osoby? To tylko jeden z wielu problemów związanych z próbami naturalizowania osoby.

Jeszcze inną kwestią jest próba naturalizacji tych teorii, które utrzymują, że z osobami mamy do czynienia dopóty, dopóki człowiek wykazuje wyższe funkcje mentalne. Wraz z ich zanikiem człowiek traci status osoby, a przez pomieszanie w tych teoriach definicji deskryptywnej z aksjologiczną

of a distinction of species alone? All these questions can be perfectly analyzed without the concept of the person. Moreover, the notion of personhood would only obscure the said bioethical questions": tamże, s. 356.

${ }^{38}$ Zob. M.J. Farah, A.S. Heberlein, Personhood and Neuroscience: Naturalizing or Anihilating?, „American Journal of Bioethics - Neuroscience” 2007, nr 7, s. 37-48.

39 „Perhaps there is a «natural kind» in the world that corresponds to persons, and by collecting the right kind of data we can discover its necessary and sufficient properties. More specifically, this approach would seek objective and clear-cut biological criteria that correspond reasonably well with most peoples' intuitions about personhood. These criteria could then be substituted for intuition in those cases where intuitions fail to agree": tamże, s. 39. 
- traci również określone prawa. Wątpliwość, jaka tutaj się pojawia, jest zauważalna dopiero wtedy, gdy zaznajomimy się chociaż trochę z anatomią i funkcjonowaniem mózgu. Zwykle łączy się wyższe funkcje mózgu z korą przedczołową. Struktura kory jednak nie jest jednolita, nie istnieje w niej jeden system neuronalny odpowiadający za wszystko, co nazywamy wyższymi funkcjami mózgu. A jeżeli tak, to co właściwie odpowiada za wyższe funkcje mózgu? Konkretnie który system bądź które powiązanie pomiędzy systemami decyduje o istnieniu osoby?

Na tak postawione pytania nauka dzisiaj nie jest w stanie odpowiedzieć. Dlatego teoretyczne dywagacje na ten temat muszą pozostać zawieszone w próżni. Badania kliniczne oraz budowa modeli odpowiednich sieci neuronalnych wykazały, że proces utraty wyższych funkcji mentalnych przebiega stopniowo, brak więc punktu, w którym następowałaby zmiana jakościowa - tak, by można uznać jej pojawienie się za granicę pomiędzy osobami a nie-osobami. W związku z tym, co zostało powiedziane, można zaryzykować twierdzenie, że ten sposób postawienia problemu osoby w kontekście osiągnięć nauk przyrodniczych jest chybiony.

\section{PODSUMOWANIE}

W związku z niezwykle ważną rolą, jaką pojęcie osoby odgrywa w dyskusjach etycznych, należy je bez wątpienia doprecyzować. W innym wypadku spór etyczny, w którym każdy z dyskutantów presuponuje swoją koncepcję osoby, nie ma szans na osiągnięcie jakiegoś zadowalającego rozwiązania. Niestety, próby dookreślenia niejasnych znaczeń charakteru „osoby” nie mogą się powieść. Ilość wypracowanych definicji jest tak wielka, tworzona w tak różnych systemach filozoficznych, że próby ich unifikacji nie mogą się udać. Wybór zatem pomiędzy np. klasyczną definicją Boecjusza, etyczną koncepcją Kanta i psychologiczną definicją Locke’a musi być czysto arbitralny.

Z kolei „osoba” w systemie prawa ma zupełnie inny charakter aniżeli w filozofii. Jest kategorią czysto normatywną, ewoluującą wraz z całościową strukturą kultur prawnych. Jej wprowadzenie nie ma na celu opisu pewnego wycinka rzeczywistości. Odgrywa ona prawną rolę "punktu zaczepienia” dla praw i obowiązków przypisywanych ludziom (i jednostkom organizacyjnym) przez ustawodawcę. Dlatego zbyt łatwe przechodzenie pomiędzy 
jakąś konkretną definicją osoby w filozofii a pojęciem osoby w prawie grozi błędem ekwiwokacji.

Neurosciences mogły okazać się zbawienne dla rozważanego problemu. Liczono do pewnego momentu na jego naturalizację. Niestety i tu okazało się to nie możliwe: kwestii „osoby” nie udało się wyjaśnić w terminach neurobiologicznych, ponieważ gdy zwracamy się do neurobiologa o pomoc, ciągle nie wiemy tak naprawdę, o co pytamy. Możemy przed tym uciec, utożsamiając osobę ze świadomością; możemy, idąc dalej, utożsamić „osobę” z ,jaźnią” rozumianą na sposób LeDouxa, ale odpowiedź, jaką uzyskamy, nie wskaże nam jasno tego, czym jest osoba. Dowiemy się jedynie, czym jest owa świadomość bądź jaźń.

Podsumowując, jeżeli analizy przeprowadzone na gruncie teologii, filozofii, bioetyki i neurobiologii wskazują na nieusuwalne problemy związane z pojęciem osoby, to czy nie rozsądniej będzie - jak chcą niektórzy porzucić to pojęcie? Pytanie jednak, czy dobrą metodą na rozwiązywanie - teoretycznie i praktycznie - ważnych zagadek filozoficznych jest ich zignorowanie? Być może wystarczyłoby rygorystyczne przestrzeganie granic pomiędzy siatkami pojęciowymi różnych dyscyplin oraz uświadomienie sobie, że nie trzeba „wylewać dziecka z kąpielą”, lecz należy poświęcić trochę więcej czasu na zrozumienie pojęć, którymi chce się operować w dyskusjach filozoficznych i etycznych. Nie mamy tu bowiem do czynienia z jednym, lecz z kilkoma pojęciami, które różnią się między sobą znaczeniem, historią i zastosowaniem. 


\section{THE CONCEPT OF PERSON - ONE OR MANY?}

\section{SUMMARY}

The paper posits the thesis that there is more than one concept of the person. Depending on the discipline where it appears, there are legal, neurobiological, philosophical and theological concepts of the person.

The concept of the person can be analyzed from four different perspectives. The results suggests that each discipline has its own definition of the person with specific meaning and function.

KEYWORDS

ethics, law, neuroscience, person, Gordijn B., Kant I., LeDoux J., Locke J. 